\title{
Analisis Intensitas Konsumsi Energi RS Medirossa Cikarang
}

\author{
Sielvya Rahma Maulida, Mia Galina, Joni Welman Simatupang \\ Study Program of Electrical Engineering, President University, Bekasi 17550, Indonesia \\ Corresponding author: miagalina@president.ac.id
}

\begin{abstract}
Medirossa Hospital is one of the health care centers in the city of Cikarang which in its operations does not only focus on the customer excellent services but also pay attention to the comfort of the environment and the completeness of the health facilities. One factor that determines the convenience of a hospital is the intensity of lighting. From the observations made by the authors of several rooms at Medirossa Cikarang Hospital, namely the casemix room, medical records, VIP treatment, and the hall leading to the second floor has less bright lighting. This observation was carried out by surveying 26 respondents who were hospital employees and visitors. From the observation, 53\% of respondents stated that the room was "not bright enough." To find out whether the lighting in the room surveyed is actually less than the Indonesian National Standard (SNI 6197: 2011), it is necessary to measure the intensity of lighting using a measuring instrument, calculating and analyzing of IKE (intensity of energy consumption) values, which can then be continued with lighting improvement if the IKE value is below the applicable lighting standard. Based on the results of calculations and analysis it was found that the value of IKE RS Medirossa Cikarang is $248.603 \mathrm{kWh} / \mathrm{m}^{2}$ year. This value indicates that electricity consumption is efficient, but has not fulfilled the applicable standards. To achieve the intensity of lighting in the rooms that have been surveyed, it is necessary to add a lamp that resulted in additional load of 748 Watt. This study aims to provide analysis and suggestion to regarding the intensity of energy consumption of RS Medirossa Cikarang for hospital lighting improvements which in turn can improve the comfort of hospital employees and visitors.
\end{abstract}

Keyword : IKE (Intensity of Energy Consumption), intensity of lighting, energy efficiency, lighting

\begin{abstract}
ABSTRAK
RS Medirossa merupakan salah satu pusat layanan kesehatan di Kota Cikarang yang dalam operasionalnya tidak hanya berfokus pada pelayanan kesehatan yang baik namun juga memperhatikan kenyamanan lingkungan serta kelengkapan fasilitas kesehatan bagi masyarakat. Salah satu factor yang menentukan kenyamanan rumah sakit adalah intensitas pencahayaan ruangan yang baik. Dari hasil observasi yang dilakukan oleh penulis terhadap beberapa ruangan di Rumah Sakit Medirossa Cikarang yaitu ruang casemix, rekam medis, perawatan VIP, dan lorong menuju ke lantai dua memiliki pencahayaan yang kurang terang. Observasi ini dilakukan dengan cara melakukan survei kepada 26 responden yang merupakan karyawan dan pengunjung rumah sakit. Dari hasil observasi didapatkan 53\% responden menyatakan bahwa ruangan tersebut "kurang terang". Untuk mengetahui apakah pencahayaan di ruangan yang telah disurvei tersebut benar kurang dari standar Standar Nasional Indonesia (SNI 6197:2011) maka perlu dilakukan pengukuran intensitas penerangan menggunakan alat ukur serta perhitungan dan analisis nilai IKE (Intensitas Konsumsi Energi), yang kemudian dapat dilanjutkan dengan upaya perbaikan pencahayaan jika nilai IKE di bawah standar penerangan yang berlaku. Berdasarkan hasil perhitungan dan analisis diperoleh bahwa nilai IKE RS Medirossa Cikarang sebesar 248.603 $\mathrm{kWh} / \mathrm{m}^{2} / \mathrm{tahun}$. Nilai ini menunjukan bahwa konsumsi energi listrik sudah efisien, namun belum memenuhi standar yang berlaku. Untuk mencapai intensitas penerangan standar pada ruangan-ruangan tersebut, maka perlu penambahan lampu yang mengakibatkan penambahan beban sebesar 748 Watt. Penelitian ini bertujuan memberikan analisis dan masukan kepada pihak RSMedirossa terkait nilai intensitas konsumsi energi RSMedirossa Cikarang guna perbaikan pencahayaan rumah sakit yang pada akhirnya dapat meningkatkan kenyamanan bagi karyawan maupun pengunjung rumah sakit.
\end{abstract}

Kata Kunci: IKE (Intensitas Konsumsi Energi) Listrik, Intensitas Penerangan, efisiensi energi, pencahayaan.

\section{PENDAHULUAN}

\section{A. Latar Belakang}

Rumah Sakit Medirossa Cikarang merupakan Rumah Sakit Swasta dengan luas bangunan $3200 \mathrm{~m}^{2}$. Merupakan RS Tipe $\mathrm{C}$ dan sudah dilengkapi dengan berbagai pelayanan penunjang medis yang memadai. Rumah sakit ini memiliki tiga lantai yang masing-masing lantainya memiliki fungsi ruang yang berbeda-beda.
Rumah sakit ini tidak hanya menawarkan pelayanan penunjang medis yang baik dan memadai. Kenyamanan pengunjung atau pasien dan juga karyawan pada aspek lain juga harus menjadi perhatian. Salah satu aspek bisa dirasakan adalah pencahayaan yang kurang optimal pada beberapa ruangan. Dari permasalahan tersebut penulis melakukan survei pada beberapa ruangan yang dirasa pencahayaannya masih kurang baik yaitu pada ruang Casemix, Rekam Medis, kamar rawat inap VIP 1, dan lorong menuju ke lantai 2. Dari hasil survei yang dilakukan pada pengunjung dan karyawan yang menempati tiap 
ruang tersebut sebanyak $53 \%$ merasakan penerangan yang kurang terang.

Audit energi merupakan sebuah proses evaluasi pemanfaatan energi untuk mengetahui profil penggunaan energi pada bangunan gedung. Proses audit energi listrik RS Medirossa Cikarang diawali dengan mengumpulkan data historis untuk mendapatkan nilai IKE (Intensitas Konsumsi Energi) Listrik. IKE merupakan istilah yang digunakan untuk menyatakan besarnya pemakaian energi listrik pada bangunan gedung dan telah diterapkan di berbagai negara (ASEAN APEC) yang dinyatakan dalam satuan $\mathrm{kWH} / \mathrm{m}^{2}$ per tahun. Besaran standar IKE bangunan gedung di Indonesia adalah sebagai berikut:

$\begin{array}{ll}\text { IKE Perkontoran } & =240 \mathrm{kWH} / \mathrm{m}^{2} / \text { tahun } \\ \text { IKE Komersial } & =240 \mathrm{kWH} / \mathrm{m}^{2} / \text { tahun } \\ \text { IKE Pusat Perbelanjaan } & =330 \mathrm{kWH} / \mathrm{m}^{2} / \text { tahun } \\ \text { IKE Hotel / Apartemen } & =300 \mathrm{kWH} / \mathrm{m}^{2} / \text { tahun } \\ \text { IKE Rumah Sakit } & =380 \mathrm{kWH} / \mathrm{m}^{2} / \text { tahun }\end{array}$

Penggunaan energi untuk sistem pencahayaan dapat dioptimalkan dengan melihat standar intensitas penerangan ruang serta besar daya yang dibutuhkan yang diatur dalam SNI-6197-2011 tentang konservasi energi pada sistem pencahayaan. Berdasarkan kondisi listrik di RS Medirossa Cikarang saat ini yang belum pernah dilakukan audit, maka penelitian ini bertujuan untuk mengetahui nilai IKE (Intensitas Konsumsi Energi) listrik di RS Medirossa Cikarang dan menganalisis apakah sistem pencahayaan di RS Medirossa Cikarang sudah sesuai dengan SNI-6197-2011 yang berlaku.

\section{LANDASAN TEORI}

\section{A. IKE (Intensitas Konsumsi Energi) Listrik}

IKE Listrik atau intensitas konsumsi energi listrik merupakan istilah untuk menyatakan besarnya pemakaian energi listrik pada suatu bangunan gedung per meter persegi per tahun. Perhitungan nilai IKE (Intensitas Konsumsi Energi) listrik ini penting karena dapat dijadikan sebagai tolak ukur dalam perhitungan peluang hemat energi berdasarkan dokumen SNI 13-6196-2011 tentang prosedur audit energi listrik [1]. Persamaan yang digunakan untuk menghitung IKE (Intensitas Konsumsi Energi) listrik adalah sebagai berikut:

$$
I K E=\frac{K_{e}}{L_{b}}
$$

Dimana:

$I K E=$ intensitas konsumsi energi listrik bangunan gedung $\left(k W h / m^{2}\right)$

$K_{e} \quad=$ konsumsi energi bangunan $(\mathrm{kWh})$

$L_{b} \quad=$ luas total bangunan gedung $\left(m^{2}\right)$

Sebagai acuan besarnya Intensitas Konsumsi Energi (IKE) listrik yang berlaku di Indonesia, penulis menggunakan hasil penelitian yang dilakukan oleh ASEAN-USAID pada tahun
1987 yang laporannya dikeluarkan pada tahun 1992 dengan rincian sebagai berikut:

- IKE perkantoran (komersial) $=240 \mathrm{kWh} / \mathrm{m}^{2} / \mathrm{tahun}$

- IKE hotel $/$ apartemen $\quad=300 \mathrm{kWh} / \mathrm{m}^{2} / \mathrm{tahun}$

- IKE pusat perbelanjaan $\quad=330 \mathrm{kWh} / \mathrm{m}^{2} / \mathrm{tahun}$

- IKE rumah sakit $=380 \mathrm{kWh} / \mathrm{m}^{2} / \mathrm{tahun}$

Untuk bangunan rumah sakit, rentang Intesitas Konsumsi Energi (IKE) listrik adalah berkisar antara $320 \mathrm{kWh} / m^{2}$ per tahun untuk batas minimum, $380 \mathrm{kWh} / \mathrm{m}^{2}$ per tahun untuk target standar, dan $450 \mathrm{kWh} / \mathrm{m}^{2}$ per tahun untuk batas maksimum. [2]

\section{B. Proses Audit Energi}

Proses Audit energi terdiri dari dua bagian yaitu audit energi awal dan audit energi rinci. Kegiatan audit energi awal meliputi pengumpulan data historis berupa jumlah total daya terpakai dilihat dari pembayaran rekening listrik di tahun sebelumnya, data dokumentasi bangunan gedung yang tersedia dan observasi perhitungan intensitas konsumsi energi (IKE). Proses audit energi awal dapat digambarkan pada diagram alir berikut (Gambar 1).

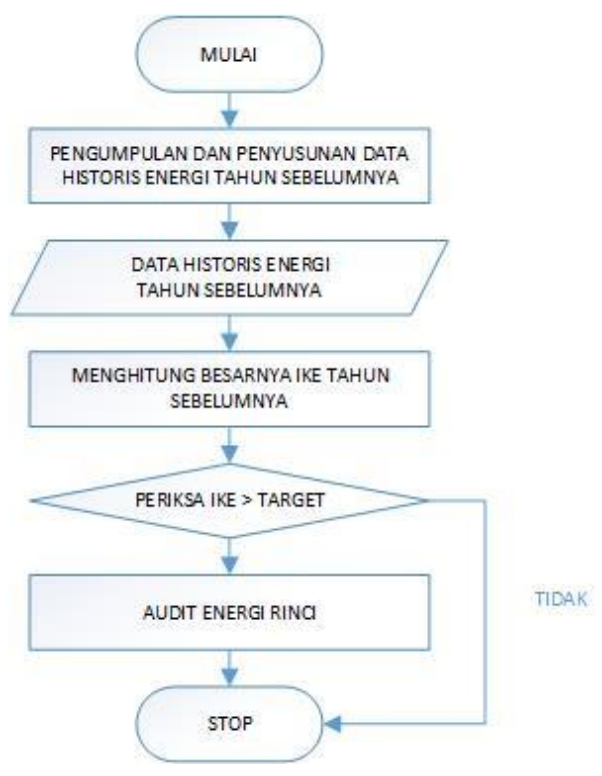

Gambar 1. Diagram alir audit energi awal menurut SNI 03-6196-2011 [1].

Kegiatan audit energi secara terperinci dilakukan apabila nilai IKE lebih besar dari nilai target yang ditentukan. Kegiatan ini meliputi pengumpulan data historis, data dokumentasi bangunan gedung yang tersedia, observasi dan pengukuran lengkap, perhitungan IKE dan kecenderungannya, potensi penghematan energi, analisis teknis dan finansial serta penyusunan laporan audit. Proses audit energi yang disarankan ditunjukkan pada Gambar 2 di bawah ini. 


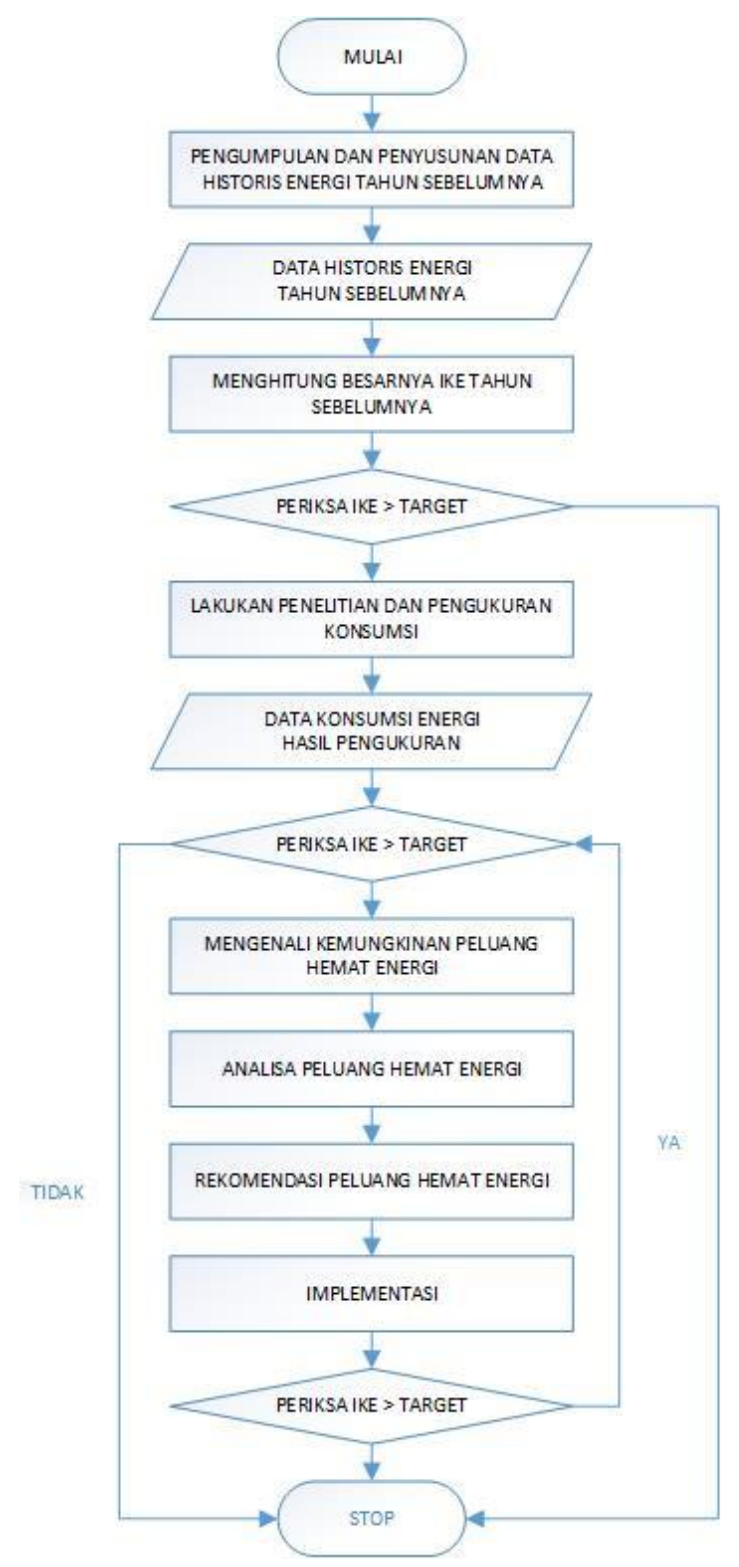

Gambar 2. Diagram alir audit energi menurut SNI 03-6196-2011 [1].

Berdasarkan diagram alir di atas maka pada proses audit energi rinci harus dilakukan analisa peluang hemat energi untuk memberikan rekomendasi penghematan energi untuk diimplementasikan agar mendapatkan nilai IKE yang standar untuk mencapai efisiensi energi.

\section{Pencahayaan}

Dalam pedoman standar pencahayaan haruslah dipahami mengenai cahaya dan sistem satuan, agar tidak mengalami kesulitan dalam hal pengukuran pencahayaan di lapangan serta batasan luas bidang kerja yang diukur. [3]

\section{Pengertian Cahaya}

Cahaya adalah suatu gejala fisis, perambatan cahaya diruang bebas dilakukan oleh gelombang-gelombang elektromagnetik yang artinya cahaya juga merupakan suatu gejala getaran. Jika dimasukan dalam suatu persamaan antara kecepatan rambat dan frekuensi maka dapat ditentukan nilai panjang gelombang sebagai berikut.

$$
\begin{array}{cl}
\text { Dimana: } & \multicolumn{1}{c}{\lambda=\frac{V}{f}} \\
\lambda & =\text { panjang gelombang }(\mathrm{m}) \\
\mathrm{V} & =\text { kecepatan rambat cahaya }(\mathrm{m} / \text { detik }) \\
\mathrm{f} & =\text { frekuensi }(\mathrm{Hz})
\end{array}
$$

\section{Satuan-satuan Pencahayaan}

a. Intensitas Cahaya

Intensitas cahaya merupakan pancaran dari sumber cahaya yang memancaran energi ke segala arah dalam satu ruangan. Menurut besaran dan satuan, satuan dari intensitas cahaya adalah candela (cd). Persamaan intensitas cahaya adalah sebagai berikut.

$$
\begin{aligned}
& \quad \mathrm{I}=\frac{F}{\omega} \\
& \text { Dimana: } \\
& \mathrm{I}=\text { Intensitas cahaya (cd) } \\
& \mathrm{F} \text { = Fluks cahaya (lumen) } \\
& \omega \quad=\text { Sudut ruang (steradian) }
\end{aligned}
$$

b. Flux Cahaya

Flux cahaya merupakan jumlah cahaya yang dipancarkan oleh sumber cahaya. Satuan dari flux cahaya adalah lumen. Jika dikaitkan dengan daya listrik satu watt cahaya memiliki panjang gelombang $555 \mathrm{~nm}$ nilainya sama dengan 680 lumen. Nilai flux cahaya dapat diketahui melalui persamaan berikut.

Dimana:

$$
F=W \times L / w
$$

$$
\begin{array}{lll}
\mathrm{F} & =\text { Fluks cahaya (lumen) } \\
\mathrm{W} & =\text { Daya lampu (Watt) } \\
\mathrm{L} / \mathrm{w} & \text { Luminous Efficacy Lamp } \\
\text { (Lumen/watt) } &
\end{array}
$$

c. Luminasi

Luminasi adalah ukuran terangnya suatu benda pada suatu cahaya maupun permukaan. Persamaan luminasi adalah sebagai berikut.

$$
\mathrm{L}=\frac{I}{A s}
$$

Dimana:

$$
\begin{aligned}
& \mathrm{L}=\text { Luminasi }\left(\mathrm{cd} / \mathrm{m}^{2}\right) \\
& \mathrm{I}=\text { Intensitas cahaya }(\mathrm{cd}) \\
& \text { As }=\text { Luas permukaan }\left(\mathrm{m}^{2}\right)
\end{aligned}
$$

d. Intensitas Penerangan

Intensitas penerangan disebut juga iluminasi atau kekuatan penerangan. Intensitas penerangan pada suatu ruangan adalah fluks cahaya yang menyinari permukaan. Satuan dari intensitas penerangan adalah lux dengan persamaan sebagai berikut.

$$
\mathrm{E}=\frac{F}{A}
$$




$$
\begin{array}{ll}
\mathrm{E} & =\text { Intensitas penerangan (lux) } \\
\mathrm{F} & =\text { Fluks cahaya (lumen) } \\
\mathrm{A} & =\text { Luas permukaan bidang }\left(\mathrm{m}^{2}\right)
\end{array}
$$

\section{Standar Pencahayaan}

Standar pencahayaan menurut Standar Nasional Indonesia SNI 6197:2011 [4] mengenai konservasi energi pada sistem pencahayaan memuat ketentuan pedoman pencahayaan pada bangunan gedung.

\begin{tabular}{|c|c|c|c|}
\hline Fungsi ruangan & $\begin{array}{c}\text { Tingkat } \\
\text { pencahayaan } \\
\text { (Lux) }\end{array}$ & Fungsi ruangan & $\begin{array}{c}\text { Tingkat } \\
\text { pencahayaan } \\
\text { (Lux) }\end{array}$ \\
\hline Rumah tinggal: & & Rumah sakit / balai pengobatan: & \\
\hline Teras & 60 & Ruang tunggu & 200 \\
\hline Ruang tamu & 150 & Ruang rawat inap & 250 \\
\hline Ruang makan & 250 & Ruang operasi, ruang bersalin & 300 \\
\hline Ruang kerja & 300 & Laboratorium & 500 \\
\hline Kamar tidur & 250 & Ruang rekreasi dan rehabilitas & 250 \\
\hline Kamar mandi & 250 & Ruang koridor siang hari & 200 \\
\hline Dapur & 250 & Ruang koridor malah hari & 50 \\
\hline Garasi & 60 & Ruang kantor staff & 350 \\
\hline Perkantoran: & & Kamar mandi \& toilet pasien & 200 \\
\hline Ruang resepsionis & 300 & Pertokoan / ruang pamer: & \\
\hline Ruang direktur & 350 & $\begin{array}{l}\text { Ruang pamer dengan proyek } \\
\text { berukuran besar }\end{array}$ & 500 \\
\hline Ruang kerja & 350 & Area penjualan kecil & 300 \\
\hline Ruang komputer & 350 & Area penjualan besar & 500 \\
\hline Ruang rapat & 300 & Area kasir & 500 \\
\hline Ruang gambar & 750 & Toko kue dan makanan & 250 \\
\hline Gudang arsip & 150 & Toko bunga & 250 \\
\hline Ruang arsip aktif & 300 & Toko buku dan alat tulis & 300 \\
\hline Ruang tangga darurat & 150 & Toko perhiasan, arloji & 500 \\
\hline Ruang parkir & 100 & Toko barang kulit dan sepatu & 500 \\
\hline Lembaga pendidikan: & & Toko pakaian & 500 \\
\hline Ruang kelas & 350 & Pasar swalayan & 500 \\
\hline Perpustakaan & 300 & Toko mainan & 500 \\
\hline Laboratorium & 500 & Toko alat elektronik & 250 \\
\hline Ruang praktek komputer & 500 & Toko alat musik \& olahraga & 250 \\
\hline Ruang laboratorium bahasa & 300 & Industri (umum) : & \\
\hline Ruang guru & 300 & Gudang & 100 \\
\hline Ruang olahraga & 300 & Pekerjaan kasar & 200 \\
\hline Ruang gambar & 750 & Pekerjaan menengah & 500 \\
\hline Kantin & 200 & Pekerjaan halus & 1000 \\
\hline Hotel dan restauran: & & Pekerjaan amat halus & 2000 \\
\hline Ruang resepsionis \& kasir & 300 & Pemeriksaan warna & 750 \\
\hline Lobi ruang serba guna & 350 & Rumah Ibadah: & \\
\hline Ruang rapat & 200 & Masjid & 200 \\
\hline Ruang makan & 300 & Gereja & 200 \\
\hline Kafetaria & 250 & Vihara & 200 \\
\hline Kamar tidur & 150 & & \\
\hline Koridor & 100 & & \\
\hline Dapur & 300 & & \\
\hline
\end{tabular}

Tabel 1. Standar Tingkat Pencahayaan Rata-Rata Menurut SNI 6197:2011 $[4]$

Tingkat pencahayaan minimal yang direkomendasikan pada Standar Nasional Indonesia SNI 6197:2011 dapat dilihat pada Tabel 1. Berdasarkan tabel tersebut dapat diketahui bahwa tingkat pecahayaan yang baik tidak kurang dari standar yang telah ditentukan pada SNI 6197:2011. Dalam standar SNI 6197:2011 daya listrik maksimum per meter persegi tidak boleh melebihi nilai pada Tabel 2 .

\begin{tabular}{|c|c|c|c|}
\hline Fungsi ruangan & $\begin{array}{c}\text { Daya } \\
\text { pencahayaan } \\
\text { maksimum } \\
\left(\mathbf{W} / \mathbf{m}^{2}\right)\end{array}$ & Fungsi ruangan & $\begin{array}{c}\text { Daya } \\
\text { pencahayaan } \\
\text { maksimum } \\
\left(\mathbf{W} / \mathbf{m}^{2}\right)\end{array}$ \\
\hline Rumah tinggal: & & Rumah sakit / balai pengobatan: & \\
\hline Teras & 3 & Ruang tunggu & 12 \\
\hline Ruang tamu & 5 & Ruang rawat jalan & 10 \\
\hline Ruang makan & 7 & Ruang rawat inap & 12 \\
\hline Ruang kerja & 7 & Ruang operasi, ruang bersalin & 10 \\
\hline Kamar tidur & 7 & Laboratorium & 15 \\
\hline Kamar mandi & 7 & Ruang gawat darurat & 15 \\
\hline Dapur & 7 & Ruang tindakan & 15 \\
\hline Garasi & 3 & Ruang rekreasi dan rehabilitas & 10 \\
\hline Perkantoran: & & Ruang Pemulihan & 8 \\
\hline Ruang resepsionis & 13 & Ruang koridor siang hari & 9 \\
\hline Ruang direktur & 13 & Ruang koridor malah hari & 3 \\
\hline Ruang kerja & 12 & Ruang kantor staff & 10 \\
\hline Ruang komputer & 12 & Kamar mandi \& toilet pasien & 7 \\
\hline Ruang rapat & 12 & Pertokoan / ruang pamer: & \\
\hline Ruang gambar & 20 & $\begin{array}{l}\text { Ruang pamer dengan proyek } \\
\text { berukuran besar }\end{array}$ & 13 \\
\hline Gudang arsip & 6 & Area penjualan kecil & 10 \\
\hline Ruang arsip aktif & 12 & Area penjualan besar & 15 \\
\hline Ruang tangga darurat & 4 & Area kasir & 15 \\
\hline Ruang parkir & 4 & Toko kue dan makanan & 9 \\
\hline Lembaga pendidikan: & & Toko bunga & 9 \\
\hline Ruang kelas & 15 & Toko buku dan alat tulis & 9 \\
\hline Perpustakaan & 11 & Toko perhiasan, arloji & 15 \\
\hline Laboratorium & 13 & Toko barang kulit dan sepatu & 15 \\
\hline Ruang praktek komputer & 12 & Toko pakaian & 15 \\
\hline Ruang laboratorium bahasa & 13 & Pasar swalayan & 15 \\
\hline Ruang guru & 12 & Toko mainan & 15 \\
\hline Ruang olahraga & 12 & Toko alat elektronik & 9 \\
\hline Ruang gambar & 20 & Toko alat musik \& olahraga & 9 \\
\hline Kantin & 8 & Industri (umum) : & \\
\hline Hotel dan restauran: & & Gudang & 5 \\
\hline Ruang resepsionis \& kasir & 12 & Pekerjaan kasar & 7 \\
\hline Lobi & 12 & Pekerjaan menengah & 15 \\
\hline Ruang serba guna & 8 & Pekerjaan halus & 25 \\
\hline Ruang rapat & 10 & Pekerjaan amat halus & 50 \\
\hline Ruang makan & 9 & Pemeriksaan warna & 20 \\
\hline Kafetaria & 8 & Rumah Ibadah: & \\
\hline Kamar tidur & 7 & Masjid & 10 \\
\hline Koridor & 5 & Gereja & 13 \\
\hline Dapur & 10 & Vihara & 10 \\
\hline
\end{tabular}

Tabel 2. Daya Listrik Maksimum Untuk Pencahayaan Menurut SNI 6197:2011 [4]

\section{Perhitungan Pada Sistem Pencahayaan}

Pada pembahasan ini dikemukakan 2 metode perhitungan untuk menentukan keperluan penerangan di dalam ruangan, yaitu:

a. Metode perhitungan dengan indeks ruang:

Menurut Muhaimin [5], hal-hal yang harus diperhitungkan dalam sistem pencahayaan adalah sebagai berikut:

- Efisiensi Armatur

Ditentukan oleh kontruksi dan bahan yang digunakan [5].

- Faktor-Faktor Refleksi

Faktor-faktor refleksi dinding ( $r w)$ dan faktor refleksi langit-langit ( $r p)$ masing-masing menyatakan bagian yang dipantulkan dari fluks cahaya yang diterima oleh dinding dan langitlangit yang mencapai bidang kerja. Faktor refleksi semu bidang pengukuran atau bidang kerja $(\mathrm{rm})$ ditentukan oleh refleksi lantai dan refleksi bagian dinding antara bidang kerja dan lantai. Umumnya untuk $(\mathrm{rm})$ ini diambil 0.1 . Menurut Muhaimin faktor refleksi berdasarkan 
warna dinding dan langit-langit dapat dilihat pada Tabel 3 berikut.

Tabel 3. Faktor Refleksi [5]

\begin{tabular}{|c|c|}
\hline Warna & Faktor Refleksi \\
\hline Putih & 0.7 \\
\hline Terang & 0.5 \\
\hline Muda & 0.3 \\
\hline Gelap & 0.1 \\
\hline
\end{tabular}

- Indeks Ruang $(k)$

Merupakan perbandingan antara ukuran-ukuran utama suatu ruangan berbentuk bujur sangkar yang dirumuskan dengan persamaan sebagai berikut:

Dimana: $\quad k=\frac{p \times l}{h(p+l)}$

$k \quad=$ Indeks ruang

$p \quad=$ panjang ruangan (meter)

$l=$ lebar ruangan (meter)

$h \quad=$ tinggi sumber cahaya di atas bidang kerja (tinggi ruang -0.80 meter)

Bidang kerja ialah suatu bidang horisontal khayalan, umumnya $0.80 \mathrm{~m}$ di atas lantai. [5]

- Faktor Penyusutan atau Deperesiasi $(k d)$

Dipengaruhi oleh akumulasi debu pada permukaan sumber cahaya, permukaan dinding yang gelap, dan umur lampu yang mempengaruhi penurunan tegangan listrik. Faktor depresiasi dibagi menjadi 3, yaitu:

- Pengotoran ringan (daerah hampir tidak berdebu)

- Pengotoran sedang atau biasa

- Pengotoran berat (daerah banyak debu)

Bila tingkat pengotoran tidak diketahui, maka faktor depresiasi yang digunakan adalah 0.8. [5]

- Efisiensi Penerangan

Efisiensi penerangan dengan nilai-nilai indeks ruangan $(k)$, faktor refleksi dinding $(r w)$, faktor refleksi langit-langit $(r p)$, dan faktor refleksi lantai $(\mathrm{rm})$, serta faktor depresiasi $(k d)$ dapat ditentukan pada Tabel 4 efisiensi penerangan.

Tabel 4. Efisiensi Penerangan [5]

\begin{tabular}{|c|c|c|c|c|c|c|c|c|c|c|c|c|c|c|}
\hline \multirow{4}{*}{$\begin{array}{l}\text { Amartur langsung } \\
\text { tak langsung }\end{array}$} & \multirow[b]{2}{*}{ v } & \multicolumn{11}{|c|}{ Efisiensi penerangan untuk keadaan baru } & \multicolumn{2}{|c|}{$\begin{array}{c}\text { Faktor depresiasi } \\
\text { untuk masa pemeliharaan }\end{array}$} \\
\hline & & & & $\mathrm{I}_{\mathrm{p}}$ & 0,7 & & & 0,5 & & & 0,3 & & & \\
\hline & & k & $r_{n}$ & 0,5 & 0,3 & 0,1 & 0,5 & 0,3 & 0,1 & 0,5 & 0,3 & 0,1 & 1 tahun 2 tahun 3 & 3 tahun \\
\hline & \multicolumn{2}{|l|}{$\%$} & & $r_{m}$ & 0,1 & & & 0,1 & & & 0,1 & & & \\
\hline GCB & & 0,5 & & 1,26 & 0,20 & 0,17 & 0,22 & 0,18 & 0,15 & 0,19 & 0,16 & 0,14 & & \\
\hline $2 \times$ TLF $36 \mathrm{~W}$ & & 0,6 & & $0,30 \mathrm{c}$ & 0,25 & 0,21 & 0,26 & 0,22 & 0,19 & 0,23 & 0,19 & 0,17 & \multicolumn{2}{|l|}{ Pengotoran ringan } \\
\hline \multirow[t]{9}{*}{ roster sejajar } & & 0,8 & & $0,38 \mathrm{c}$ & 0,32 & 0,28 & 0,33 & 0,29 & 0,25 & 0,28 & 0,25 & 0,23 & $0,85 \quad 0,80$ & 0,70 \\
\hline & & 1 & & 0,43 & 0,38 & 0,34 & 0,38 & 0,34 & 0,30 & 0,32 & 0,29 & 0,27 & & \\
\hline & & 1,2 & & 0,47 & 0,42 & 0,38 & 0,41 & 0,37 & 0,34 & 0,35 & 0,32 & 0,30 & \multicolumn{2}{|l|}{ Pengotoran sedang } \\
\hline & & 1,5 & & 0,51 & 0,47 & 0,43 & 0,45 & 0,41 & 0,38 & 0,38 & 0,36 & 0,33 & $0,80 \quad 0,70$ & 0,65 \\
\hline & 38 & 2 & & 0,56 & 0,52 & 0,49 & 0,49 & 0,46 & 0,43 & 0,42 & 0,40 & 0,38 & & \\
\hline & $\uparrow$ & 2,5 & & 0,59 & 0,56 & 0,52 & 0,52 & 0,49 & 0,46 & 0,44 & 0,42 & 0,40 & \multicolumn{2}{|l|}{ Pengotoran berat } \\
\hline & 81 & 3 & & 0,61 & 0,58 & 0,55 & 0,54 & 0,51 & 0,49 & 0,46 & 0,44 & 0,42 & $x \quad x$ & $x$ \\
\hline & $\downarrow$ & 4 & & 0,64 & 0,62 & 0,59 & 0,56 & 0,54 & 0,52 & 0,48 & 0,47 & 0,45 & & \\
\hline & 43 & 5 & & 0,66 & 0,64 & 0,62 & 0,58 & 0,56 & 0,54 & 0,50 & 0,48 & 0,47 & & \\
\hline
\end{tabular}

- Faktor Utility (kp)

Faktor utility dapat ditentukan dengan tabel efisiensi penerangan dengan mencari nilai indeks ruang (k) yang tepat. Jika nilai (k) tidak terdapat secara tepat pada tabel, maka faktor utility diperoleh dengan metode interpolasi yaitu: [5]

$k p=k p_{1}+\frac{k-k_{1}}{k_{2}-k_{1}}\left(k p_{2}-k p_{1}\right)$
Dimana:

$k p \quad=$ faktor utility yang akan ditentukan

$k p_{1}=$ faktor utility batas bawah

$k p_{2}=$ faktor utility batas atas

$k=$ indeks ruangan yang akan ditentukan

$k_{1}=$ indeks ruangan batas bawah

$k_{2}=$ indeks ruangan batas atas

- Jumlah Lampu

Untuk menetukan jumlah lampu digunakan persamaan berikut:

Dimana,

$$
N=\frac{E \times A}{\phi \times k p \times k d}
$$

$N=$ Jumlah lampu (buah)

$E$ = Intensitas penerangan (Lux)

$A=$ Luas ruang $\left(\mathrm{m}^{2}\right)$

$\phi=$ Fluks pada sumber cahaya (Lumen)

$k p=$ Faktor utility

$k d=$ Faktor depresiasi

b. Metoda Lumen

Metoda yang digunakan untuk menghitung intensitas penerangan rata-rata pada suatu ruang disebut dengan metoda lumen. Persamaan yang digunakan untuk menghitung banyaknya jumlah lampu sama dengan metoda perhitungan dengan indeks ruang. Yang membedakan adalah pada metoda lumen perhitungan jumlah lampu untuk penerangan langsung pada kondisi baru besarnya faktor depresiasi telah ditentukan yaitu 0.8 dan faktor utilitas sebesar 0.6. [6] 


\section{METODOLOGI PENELITIAN}

A. Flowchart Metodologi Penelitian

Langkah-langkah yang dilakukan dalam penelitian, dijelaskan melalui flowchart di bawah ini (Gambar 3.)

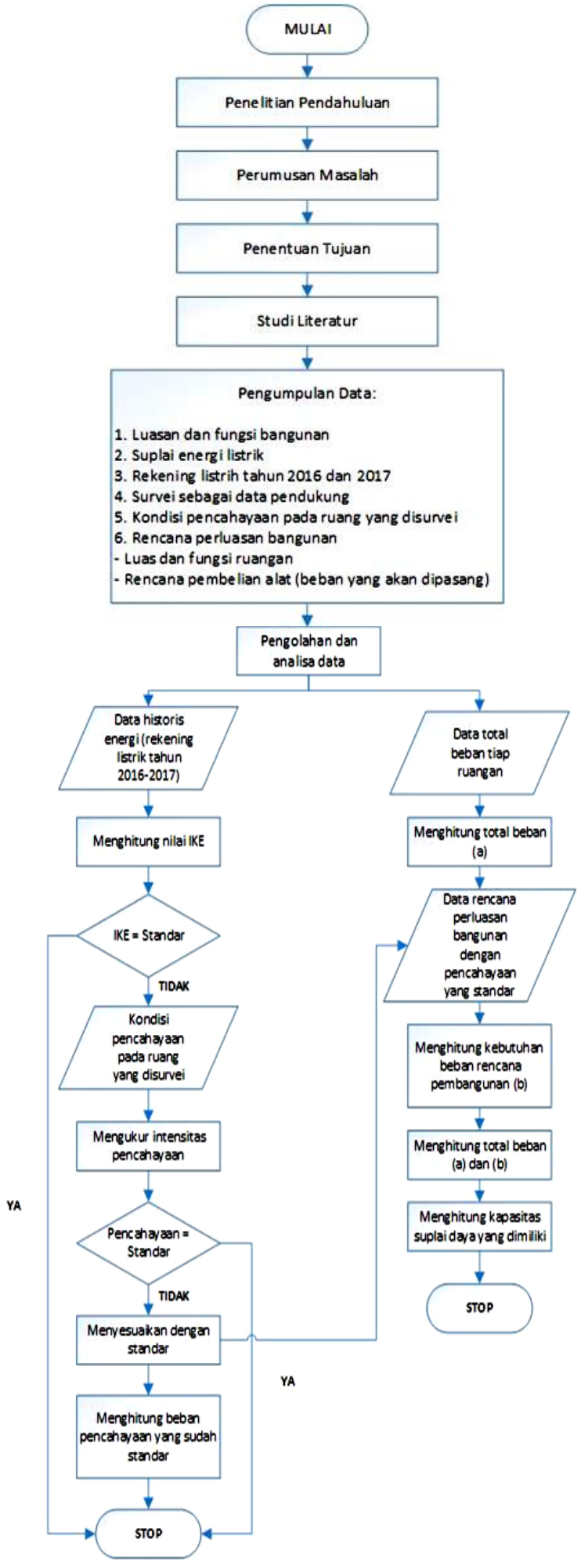

Gambar 3. Flowchart Metodologi Penelitian.

\section{B. Pengumpulan Data}

B.1 Bangunan Gedung Rumah Sakit Medirossa Cikarang

Rumah Sakit Medirossa Cikarang memiliki gedung utama 3 lantai dan gedung satu lantai yang berada dibagian belakang gedung utama dengan luas total bangunan $3200 \mathrm{~m}^{2}$. Pada lantai satu gedung utama terdapat ruang-ruang yang difungsikan sebagai tempat untuk administrasi pelayanan medis, ruang poliklinik, ruang ICU, ruang operasi, ruang penunjang medis, farmasi, dan rekam medis. Di lantai lebih didominasi oleh ruang-ruang perawatan di antaranya ruang perawatan VIP, kelas utama, kelas 1, perawatan anak, sedangkan pada lantai tiga terdapat ruang perawatan isolasi, kelas 2, dan kelas 3. Ruangan-ruangan tersebut sebagai objek penelitian yang dilakuan, dimana akan dilakukan perhitungan nilai IKE (Intensitas Konsumsi Energi) listrik per total luasan bangunan serta total beban terpasang dari setiap ruangan tersebut.

B.2 Sumber Energi Listrik Rumah Sakit Medirossa Cikarang Sumber energi listrik pada Rumah Sakit Medirossa Cikarang berasal dari PLN (Perusahaan Listrik Negara) yang memiliki suplai daya listrik sebesar $200 \mathrm{kVA}$ dan 66 $\mathrm{kVA}$ dan menggunakan trafo distribusi yang berkapasitas masing-masing $300 \mathrm{kVA}$ dan $150 \mathrm{kVA}$. Sumber daya listrik PLN ini diperoleh dari jaringan tegangan menengah $20 \mathrm{kV}$ yang diturunkan menjadi tegangan rendah 380/220 V tiga phasa dengan menggunakan trafo step down. Selain sumber energi dari PLN Rumah Sakit Medirossa Cikarang juga memiliki sumber listrik cadangan yaitu sebuah generator set dengan suplai daya listrik sebesar $400 \mathrm{kVA}$. Generator set ini beroperasi secara otomatis dan akan menyalurkan listrik ke seluruh gedung RS Medirossa Cikarang apabila terjadi pemadaman listrik dari PLN. Sumber energi listrik ini kemudian didistribusikan ke panel-panel yang berada pada setiap lantai di gedung Rumah Sakit Medirossa Cikarang.

\section{B.3 Data Konsumsi Energi Listrik}

IKE (Intensitas Konsumsi Energi) Listrik dapat dihitung setelah mengetahui luas total bangunan $\left(\mathrm{m}^{2}\right)$ berdasarkan data bangunan yang disebutkan pada poin B.1 dan total daya pada data historis konsumsi energi listrik yang didapatkan dari bukti pembayaran rekening listrik tahun 2016-2017. Konsumsi energi listrik Januari 2016 sampai Desember 2017. Besar energi total $\mathrm{kWh}$ selama 12 bulan tahun 2016 adalah $885.173 \mathrm{kWh}$ dan tahun 2017 adalah $910.729 \mathrm{kWh}$.

\section{B.4 Data Penerangan \\ B.4.1 Pengukuran Intensitas Penerangan}

Pengukuran ini dilakukan dengan metode pengukuran yang direkomendasikan oleh Badan Standarisasi Nasional (BSN) yaitu yang tertulis pada SNI 16-7062-2004 mengenai Pengukuran Intensitas Penerangan di Tempat Kerja [7].

\section{B.4.2 Metode Pengukuran}

Pengukuran intensitas penerangan ini memakai alat luxmeter yang hasilnya dapat langsung dibaca. Alat ini mengubah energi cahaya menjadi energi listrik, kemudian energi listrik dalam bentuk arus digunakan untuk 
menggerakan arus skala. Untuk alat digital, energi listrik diubah menjadi angka yang dapat dibaca pada layar monitor. [7].

\section{B.4.3 Peralatan}

Luxmeter adalah alat ukur yang digunakan untuk mengukur intensitas cahaya. Alat ini terdiri dari sensor cahaya, layar panel, tombol off/on, dan tombol range. Sesnsor yang digunakan adalah photo diode yang merupakan jenis sensor cahaya atau optik.

\section{B.4.4 Penentuan titik pengukuran}

Berdasarkan SNI 16-7062-2004 mengenai Pengukuran Intensitas Penerangan di Tempat Kerja, penentuan titik dibedakan atas:

a). Penerangan setempat:

Objek kerja berupa meja kerja maupun peralatan. Bila merupakan meja kerja, pengukuran dapat dilakukan di atas meja yang ada.

b). Penerangan Umum:

Titik potong garis horizontal panjang dan lebar ruangan setiap jarak tertentu setinggi satu meter dari lantai. Jarak tertentu tersebut dibedakan berdasarkan luas ruangan sebagai berikut:

- $\quad$ Luas ruangan kurang dari $10 \mathrm{~m}^{2}$ :

Titik potong garis horizontal panjang dan lebar ruangan pada jarak setiap 1 (satu) meter. [7]

- Luas ruangan antara $10 \mathrm{~m}^{2}$ sampai $100 \mathrm{~m}^{2}$ : Titik potong garis horizontal panjang dan lebar ruangan pada jarak setiap 3 (tiga) meter. [7]

- Luas ruangan lebih dari $100 \mathrm{~m}^{2}$ : Titik potong garis horizontal panjang dan lebar ruangan pada jarak setiap 6 (enam) meter. [7]

\section{B.4.5 Persyaratan Pengukuran}

- Pintu ruangan dalam keadaan sesuai dengan kondisi tempat pekerjaan dilakukan.

- Lampu ruangan dalam keadaan dinyalakan sesuai dengan kondisi pekerjaan.

\section{B.5 Hasil Pengukuran}

Dari pengukuran di ruang yang telah dilakukan survei, diperoleh hasil sebagai berikut

\section{a). Ruang Casemix}

\section{Jenis ruang : Penerangan Setempat}

Luas : $20 \mathrm{~m}^{2}$

Fungsi ruang : Coding Diagnosa, Input data, dan membuat laporan

Titik penerangan : Objek kerja berupa 7 buah meja kerja (Gambar 4)

Jenis lampu dan Daya: 2 buah lampu TL 36 Watt

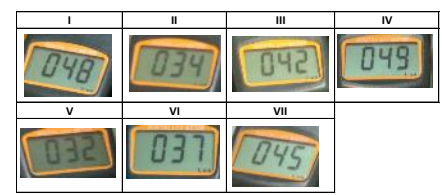

Gambar 4. Hasil pengukuran intensitas penerangan ruang casemix

\section{b). Ruang Rekam Medis}

Jenis ruang : Penerangan Setempat
Luas $\quad: 32,5 \mathrm{~m}^{2}$

Fungsi ruang : Penulisan resume medis, Input data, penyimpanan status rekam medis, dan membuat laporan Titik penerangan : Objek kerja berupa 4 buah meja kerja dan 3 rak pengambilan status rekam medis (Gambar 5).

Jenis lampu dan Daya: - 5 buah lampu TL 36 Watt

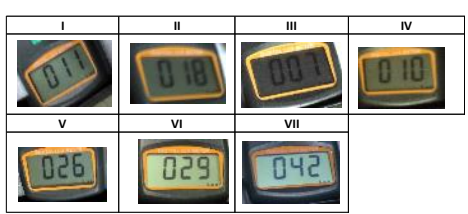

Gambar 5. Hasil pengukuran intensitas penerangan ruang rekam medis.

\section{c). Kamar Rawat VIP 1}

Jenis ruang : Penerangan Setempat

Luas $\quad: 30 \mathrm{~m}^{2}$

Fungsi ruang : Kamar rawat inap

Titik penerangan : Tempat istirahat pasien dan tempat jaga pasien (Gambar 6).

Jenis lampu dan Daya: 2 buah lampu TL masing-masing 36 Watt, 2 buah lampu esensial 14 Watt, dan 2 buah lampu tidur 14 Watt.

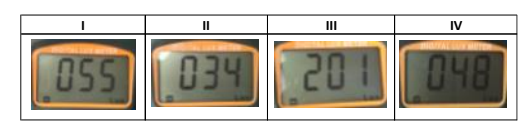

Gambar 6. Hasil pengukuran intensitas penerangan kamar rawat VIP 1.

\section{d). Lorong A}

Jenis ruang : Penerangan Umum

Luas : $30 \mathrm{~m}^{2}$

Fungsi ruang : Akses pertama menuju ke lantai 2

Titik penerangan : titik potong garis horizontal panjang dan lebar ruangan pada jarak setiap $3 \mathrm{~m}$ (Gambar 7).

Jenis lampu dan Daya: 2 buah lampu TL 36 Watt

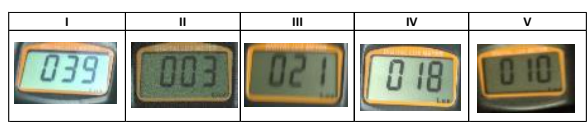

Gambar 7. Hasil pengukuran intensitas penerangan lorong A.

\section{e). Lorong B}

Jenis ruang : Penerangan Umum

Luas : $30 \mathrm{~m}^{2}$

Fungsi ruang : Akses kedua menuju ke lantai 2

Titik penerangan : titik potong garis horizontal panjang dan lebar ruangan pada jarak setiap 3 meter (Gambar 8).

Jenis lampu dan Daya : 2 buah lampu TL masingmasing 36 Watt

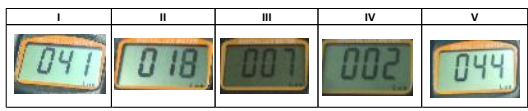

Gambar 8. Hasil pengukuran intensitas penerangan lorong B

\section{ANALISIS DATA}




\section{A. Analisis IKE (Intensitas Konsumsi Energi) Listrik}

Berdasarkan data historis konsumsi energi listrik tahun 2016-2017 telah diketahui bahwa nilai konsumsi energi $\left(\mathrm{K}_{\mathrm{e}}\right)$ listrik total $\mathrm{kWh}$ tahun 2016 sebesar $885.173 \mathrm{kWh}$ dan tahun 2017 sebesar $910.729 \mathrm{kWh}$ dengan luas bangunan $\left(\mathrm{L}_{\mathrm{b}}\right) \mathrm{RS}$ Medirossa Cikarang saat ini adalah $3200 \mathrm{~m}^{2}$. Menggunakan persamaan (2.1) maka dapat dihitung nilai IKE sebagai berikut:

$$
I K E=\frac{K_{e}}{L_{b}}
$$

Dimana:

$I K E=$ intensitas konsumsi energi listrik bangunan gedung $\left(\mathrm{kWh} / \mathrm{m}^{2}\right)$

$K_{e}=$ konsumsi energi bangunan $(\mathrm{kWh})$

$L_{b} \quad=$ luas total bangunan gedung $\left(m^{2}\right)$

$I K E(2016)=\frac{885.173 \mathrm{kWh} \text { per tahun }}{3200 \mathrm{~m}^{2}}=276.617 \mathrm{kWh}$ per tahun $/ \mathrm{m}^{2}$

$I K E(2017)=\frac{910.729 \mathrm{kWh} \text { per tahun }}{3200 \mathrm{~m}^{2}}=284.603 \mathrm{kWh}$ per tahun $/ \mathrm{m}^{2}$

Dari perhitungan di atas diperoleh bahwa nilai IKE tahun 2017 lebih besar dari tahun 2016, hal ini dikarenakan bangunan lantai 3 yang sudah ada sejak tahun 2015 namun ruang perawatan lantai $3 \mathrm{~B}$ dan ruang perawatan isolasi baru mulai diopersikan pada awal tahun 2017. Nilai IKE yang diperoleh tahun 2016 adalah $276.617 \mathrm{kWh} / \mathrm{tahun} / \mathrm{m}^{2}$ dan $284.603 \mathrm{kWh} /$ tahun / $\mathrm{m}^{2}$ untuk tahun 2017 artinya nilai IKE untuk bangunan RS Medirossa Cikarang lebih kecil dari nilai IKE standar pada prosedur audit energi listrik SNI 13619-2000 yaitu sebesar $380 \mathrm{kWh} / \mathrm{tahun} / \mathrm{m}^{2}$ untuk bangunan rumah sakit. Nilai IKE yang lebih kecil dari standar menunjukan bahwa penggunaan energi listrik di RS Medirossa Cikarang termasuk dalam kategori efisien. Namun penggunaan energi yang efisien ini belum tentu efektif atau belum sesuai dengan standar. Untuk mengetahuinya, salah satu langkah yang dapat ditempuh adalah mengetahui kondisi pencahayaan apakah sudah sesuai dengan standar.

\section{B. Analisis Hasil Pengukuran Intensitas Penerangan} Analisis hasil pengukuran intensitas penerangan pada ruang casemix, rekam medis, lorong A, lorong B, dan kamar rawat VIP 1 adalah sebagai berikut (Tabel 5):

Tabel 5. Rata-Rata Hasil Pengukuran Intensitas Penerangan

\begin{tabular}{|c|c|c|c|c|c|c|c|c|c|c|}
\hline \multirow{2}{*}{ No } & \multirow{2}{*}{ Ruang } & \multirow{2}{*}{ Jenis Ruang } & \multicolumn{7}{|c|}{ Hasil Pengukuran (Lux) } & \multirow{2}{*}{$\begin{array}{c}\text { Rata-rata } \\
\text { (Lux) }\end{array}$} \\
\hline & & & I & II & III & IV & $\mathbf{V}$ & VI & VII & \\
\hline 1 & Casemix & Setempat & 48 & 34 & 42 & 49 & 32 & 37 & 45 & 41.00 \\
\hline 2 & Rekam Medis & Setempat & 11 & 18 & 7 & 10 & 26 & 29 & 42 & 20.43 \\
\hline 3 & Lorong A & Umum & 39 & 3 & 21 & 18 & 10 & & & 18.20 \\
\hline 4 & Lorong B & Umum & 41 & 18 & 7 & 2 & 44 & & & 22.40 \\
\hline 5 & VIP & Setempat & 201 & 48 & 55 & 34 & & & & 84.50 \\
\hline
\end{tabular}

Dalam pengukuran setiap ruangan diambil nilai rata-rata dari titik pengukuran yang sesuai dengan jenis ruangan pada metode pengukuran menurut SNI 16-7062-2004 mengenai "Pengukuran Intensitas Penerangan di Tempat Kerja".
Pengukuran Intensitas penerangan menggunakan luxmeter sesuai dengan keadaan yang berlangsung sehari-hari (Tabel 6)

Tabel 6. Standar Intensitas Penerangan
\begin{tabular}{|c|l|l|c|}
\hline \multirow{2}{*}{ No } & \multirow{2}{*}{ Ruang } & \multicolumn{2}{|c|}{ SNI 6197:2011 } \\
\cline { 3 - 4 } & & Jenis Ruang & $($ Lux $)$ \\
\hline 1 & Casemix & Ruang Kerja & 350 \\
\hline 2 & Rekam Medis & Arsip Aktif & 300 \\
\hline 3 & VIP & Rawat Inap & 250 \\
\hline 4 & Lorong A & Koridor & 200 \\
\hline 5 & Lorong B & Koridor & 200 \\
\hline
\end{tabular}

Tabel 6 menunjukkan nilai standar intensitas penerangan dan daya maksimum yang harus dicapai sesuai dengan SNI 6197:2011 pada Tabel 2 mengenai konservasi energi pada sistem pencahayaan. Setelah diketahui hasil pengukuran dan standar intensitas pencahayaan, kemudian dilakukan perbandingan antara kedua data tersebut untuk mengetahu apakah intensitas penerangan di ruang casemix, rekam medis, lorong A, lorong B, dan kamar rawat VIP 1 sudah standar (Tabel 7).

Tabel 7. Persentase Perbandingan Pengukuran Dan Standar Intensitas Pencahayaan

\begin{tabular}{|r|l|r|c|r|}
\hline No & \multicolumn{1}{|c|}{ Ruang } & $\begin{array}{c}\text { Rata-rata } \\
\text { (Lux) }\end{array}$ & $\begin{array}{c}\text { Standar } \\
\text { (Lux) }\end{array}$ & Persentase \\
\hline 1 & Casemix & 41.00 & 350 & 11.71 \\
\hline 2 & Rekam Medis & 20.43 & 300 & 6.81 \\
\hline 3 & VIP & 84.50 & 250 & 33.80 \\
\hline 4 & Lorong A & 18.20 & 200 & 9.10 \\
\hline 5 & Lorong B & 22.40 & 200 & 11.20 \\
\hline
\end{tabular}

Dari pengukuran setiap ruangan diambil nilai rata-rata dari total titik pengukuran, kemudian dibandingkan dengan standar intensitas penerangan menurut badan standarisasi nasional pada SNI 6197:2011 pada Tabel 2 dan didapatkan hasil bahwa kualitas intensitas penerangan di ruang casemix adalah $11.71 \%$, rekam medis $6.81 \%$, lorong A $9.10 \%$, lorong B $11.20 \%$ dan kamar rawat VIP $133.80 \%$.

Jika dilihat dari hasil analisa tersebut seluruh ruang yang telah diukur intensitas penerangannya memiliki persentase yang kecil jika dibandingkan dengan standar intensitas penerangan SNI 6197:2011. Hal ini menunjukan bahwa intensitas di ruangan tersebut kurang baik dan perlu dilakukan perbaikan pada sistem pencahayaan untuk mencapai standar intensitas pencahayaan.

\section{B.1 Analisis Perhitungan Perbaikan Intensitas Penerangan}

\section{Ruang Casemix}

Perhitungan jumlah lampu pada ruang casemix diuraikan secara rinci sebagai berikut:

a. Data ruangan

Panjang ruangan $(p) \quad=5.0 \mathrm{~m}$

Lebar ruangan $(l) \quad=4.0 \mathrm{~m}$

Tinggi ruangan $(t) \quad=3.0 \mathrm{~m}$

Tinggi sumber cahaya di atas bidang kerja 
$(h)=2.2 \mathrm{~m}(3.0 \mathrm{~m}-0.8 \mathrm{~m})$

b. Indeks ruangan $(k)$

Dengan menggunakan persamaan 7 maka indeks ruangan ditentukan sebagai berikut:

$$
\begin{aligned}
& \mathrm{k}=\frac{p \times l}{h(p+l)} \\
& \mathrm{k}=\frac{5 \times 4}{2.2(5+4)}=1.01
\end{aligned}
$$

c. Faktor refleksi

Dengan mengacu pada Tabel 3 dan 4, maka faktor refleksi di ruang casemix adalah sebagai berikut:

Faktor refleksi langit-langit $(r p) \quad=0.7$

Faktor refleksi dinding $(r w) \quad=0.5$

Faktor refleksi lantai $(\mathrm{rm}) \quad=0.1$

d. Efisiensi penerangan

Dari perhitungan indeks ruangan dan ketentuan faktor refleksi mengacu pada tabel 2.6 tentang efisiensi penerangan maka diperoleh efisiensi penerangan sebagai berikut:

$\begin{array}{ll}k_{1} & =1.0 \\ k_{2} & =1.2 \\ k p_{1} & =0.43 \\ k p_{2} & =0.47\end{array}$

e. Faktor utility $(k p)$

Dengan mengunakan persamaan 8 maka besarnya faktor utility adalah sebagai berikut:

$$
\begin{aligned}
& k p=k p_{1}+\frac{k-k_{1}}{k_{2}-k_{1}}\left(k p_{2}-k p_{1}\right) \\
& \mathrm{kp}=0.43+\frac{1.01-1}{1.2-1}(0.47-0.43)=0.432
\end{aligned}
$$

f. Penentuan jumlah lampu:

- Menggunakan lampu TL-D 36 W/54-762 = 36 Watt

- Fluks lampu = 2500 lumen

- Standar intensitas penerangan berdasarkan tabel 2.1 ( $\mathrm{E}=350$ lux $)$

- Fakror depresiasi $(k d)=0.8$

g. Jumlah lampu

Berdasarkan persamaan 9 maka jumlah lampu yang dibutuhkan adalah sebagai berikut:

$$
\begin{aligned}
N & =\frac{E \times A}{\phi \times k p \times k d} \\
N & =\frac{350 \text { lux } \times 20 \mathrm{~m}^{2}}{2500 \times 0.432 \times 0.8}=8.10 \approx 8
\end{aligned}
$$

Dari perhitungan di atas diketahui banyaknya jumlah lampu yang harus dipasang di ruang casemix sebanyak 8 buah memakai jenis lampu yang sama dengan kondisi awal untuk mencapai intensitas penerangan yang standar yaitu 350 lux.

h. Perbandingan Kondisi Awal dan Kondisi Standar Perbandingan ini menunjukan perbedaan kondisi ruang pada keadaan awal dan keadaan standar yang dianjurkan (Tabel 8).
Tabel 8. Perbandingan Kondisi Awal Dan Kondisi Standar Ruang Casemix

\begin{tabular}{|c|c|c|c|c|c|c|c|}
\hline \multirow{2}{*}{ Ruang } & \multirow{2}{*}{$\begin{array}{c}\text { Luas } \\
\left(\mathbf{m}^{\mathbf{2}}\right)\end{array}$} & $\begin{array}{c}\text { Jenis } \\
\text { lampu }\end{array}$ & $\begin{array}{c}\text { Jumlah } \\
\text { Lampu }\end{array}$ & $\begin{array}{c}\text { Intensitas } \\
\text { Penerang }\end{array}$ & $\begin{array}{c}\text { Jenis } \\
\text { lampu }\end{array}$ & $\begin{array}{c}\text { Jumlah } \\
\text { Lampu }\end{array}$ & $\begin{array}{c}\text { Intensitas } \\
\text { Penerangan } \\
\text { (Lux) }\end{array}$ \\
\hline Casemix & 20 & $\begin{array}{c}\text { TL 36 } \\
\text { Watt }\end{array}$ & 2 & 41.00 & $\begin{array}{c}\text { TL 36 } \\
\text { Watt }\end{array}$ & 8 & 350 \\
\hline
\end{tabular}

Tabel di atas menunjukan bahwa kecilnya intensitas penerangan pada hasil pengukuran salah satu penyebabnya adalah kurangnya jumlah lampu yang seharusnya dipasang pada ruangan dengan luas $20 \mathrm{~m}^{2}$ dengan sumber pencahayaan lampu TL-D 36W/54-765 ISL/25.

\section{Ruang Rekam Medis}

Perhitungan jumlah lampu pada ruang casemix diuraikan secara rinci sebagai berikut:

a. Data ruangan

$\begin{array}{ll}\text { Panjang ruangan }(p) & =6.0 \mathrm{~m} \\ \text { Lebar ruangan }(l) & =5.5 \mathrm{~m} \\ \text { Tinggi ruangan }(t) & =3.0 \mathrm{~m}\end{array}$

Tinggi sumber cahaya di atas bidang kerja $(h)=2.2$ $\mathrm{m}(3.0 \mathrm{~m}-0.8 \mathrm{~m})$

b. Indeks ruangan $(k)$

Dengan menggunakan persamaan 7 maka indeks ruangan ditentukan sebagai berikut:

$$
\mathrm{k}=\frac{p \times l}{h(p+l)}=\frac{6 \times 5.5}{2.2(6+5.5)}=1.28
$$

c. Faktor refleksi

Dengan mengacu pada Tabel 3 dan 4, maka faktor refleksi ruang rekam medis adalah:

Faktor refleksi langit-langit $(r p) \quad=0.7$

Faktor refleksi dinding $(r w) \quad=0.5$

Faktor refleksi lantai $(\mathrm{rm}) \quad=0.1$

d. Efisiensi penerangan

Dari perhitungan indeks ruangan dan ketentuan faktor refleksi mengacu pada Tabel 4 tentang efisiensi penerangan maka diperoleh efisiensi penerangan sebagai berikut:

$$
\begin{array}{ll}
k_{1} & =1.2 \\
k_{2} & =1.5 \\
k p_{1} & =0.47 \\
k p_{2} & =0.51
\end{array}
$$

e. Faktor utility $(k p)$

Dengan mengunakan persamaan 8 maka besarnya faktor utility adalah sebagai berikut:

$$
\begin{aligned}
& k p=k p_{1}+\frac{k-k_{1}}{k_{2}-k_{1}}\left(k p_{2}-k p_{1}\right) \\
& \mathrm{kp}=0.47+\frac{1.28-1.2}{1.5-1.2}(0.51-0.47)=0.486
\end{aligned}
$$

f. Penentuan jumlah lampu

- Menggunakan lampu TL-D $36 \mathrm{~W} / 54-762=36$ Watt 
- Fluks lampu = 2500 lumen

- Standar intensitas penerangan berdasarkan tabel $2.1(\mathrm{E}=300$ lux $)$

- $\quad$ Fakror depresiasi $(k d)=0.8$

g. Jumlah lampu

Berdasarkan persamaan 9 maka jumlah lampu yang dibutuhkan adalah sebagai berikut:

$$
\begin{aligned}
& N=\frac{E \times A}{\phi \times k p \times k d} \\
& N=\frac{300 \operatorname{lu} \times 32.5 \mathrm{~m}^{2}}{2500 \times 0.486 \times 0.8}=10.03 \approx 10
\end{aligned}
$$

Dari perhitungan di atas diketahui banyaknya jumlah lampu yang harus dipasang di ruang rekam medis sebanyak 10 buah memakai jenis lampu yang sama dengan kondisi awal untuk mencapai intensitas penerangan yang standar yaitu 300 lux.

h. Perbandingan Kondisi Awal dan Kondisi Standar Perbandingan ini menunjukan perbedaan kondisi ruang pada keadaan awal dan keadaan standar yang dianjurkan (Tabel 9).

Tabel 9. Perbandingan Kondisi Awal Dan Kondisi Standar

\begin{tabular}{|c|c|c|c|c|c|c|c|}
\multicolumn{10}{|c|}{ Ruang Rekam Medis } \\
\cline { 5 - 8 } Ruang & $\begin{array}{c}\text { Luas } \\
\left(\mathbf{m}^{\mathbf{2}}\right)\end{array}$ & $\begin{array}{c}\text { Jenis } \\
\text { lampu }\end{array}$ & $\begin{array}{c}\text { Jumlah } \\
\text { Lampu }\end{array}$ & $\begin{array}{c}\text { Intensitas } \\
\text { Penerang }\end{array}$ & $\begin{array}{c}\text { Jenis } \\
\text { lampu }\end{array}$ & $\begin{array}{c}\text { Jumlah } \\
\text { Lampu }\end{array}$ & $\begin{array}{c}\text { Intensitas } \\
\text { Penerangan } \\
\text { (Lux) }\end{array}$ \\
\hline $\begin{array}{c}\text { Rekam } \\
\text { Medis }\end{array}$ & 32.5 & $\begin{array}{c}\text { TL 36 } \\
\text { Watt }\end{array}$ & 5 & 20.43 & $\begin{array}{c}\text { TL 36 } \\
\text { Watt }\end{array}$ & 10 & 300 \\
\hline
\end{tabular}

Tabel di atas menunjukan bahwa kecilnya intensitas penerangan pada hasil pengukuran salah satu penyebabnya adalah kurangnya jumlah lampu yang seharusnya dipasang pada ruangan dengan luas $20 \mathrm{~m}^{2}$ dengan sumber pencahayaan lampu TL-D 36W/54765 ISL/25.

\section{Kamar Rawat VIP 1}

Perhitungan jumlah lampu pada ruang casemix diuraikan secara rinci sebagai berikut:

a. Data ruangan

$$
\begin{array}{ll}
\text { Panjang ruangan }(p) & =6.0 \mathrm{~m} \\
\text { Lebar ruangan }(l) & =5.0 \mathrm{~m} \\
\text { Tinggi ruangan }(t) & =3.0 \mathrm{~m}
\end{array}
$$

Tinggi sumber cahaya di atas bidang kerja $(h)=2.2$ $\mathrm{m}(3.0 \mathrm{~m}-0.8 \mathrm{~m})$

b. Indeks ruangan $(k)$

Dengan menggunakan persamaan 7 maka indeks ruangan ditentukan sebagai berikut:

$$
\begin{aligned}
k & =\frac{p \times l}{h(p+l)} \\
\mathrm{k} & =\frac{6 \times 5}{2.2(6+5)}=1.24
\end{aligned}
$$

c. Faktor refleksi

Dengan mengacu pada Tabel 3 dan 4, maka faktor refleksi di kamar VIP 1 adalah:

$\begin{array}{ll}\text { Faktor refleksi langit-langit }(\mathrm{rp}) & =0.7 \\ \text { Faktor refleksi dinding }(\mathrm{rw}) & =0.5 \\ \text { Faktor refleksi lantai }(\mathrm{rm}) & =0.1\end{array}$ d. Efisiensi penerangan

Dari perhitungan indeks ruangan dan ketentuan faktor refleksi mengacu pada Tabel 4 tentang efisiensi penerangan maka diperoleh efisiensi penerangan sebagai berikut:

$\begin{array}{ll}k_{1} & =1.2 \\ k_{2} & =1.5 \\ k p_{1} & =0.47 \\ k p_{2} & =0.51\end{array}$

e. Faktor utility $(k p)$

Dengan mengunakan persamaan 8 maka besarnya faktor utility adalah sebagai berikut:

$$
\begin{aligned}
& k p=k p_{1}+\frac{k-k_{1}}{k_{2}-k_{1}}\left(k p_{2}-k p_{1}\right) \\
& \mathrm{kp}=0.47+\frac{1.24-1.2}{1.5-1.2}(0.51-0.47)=0.475
\end{aligned}
$$

f. Penentuan jumlah lampu

- Menggunakan lampu TL-D 36 W/54-762 = 36 Watt dan Essential $=14$ Watt

- Fluks lampu TL = 2500 lumen

- Fluks lampu Essential = 850 lumen

- Standar intensitas penerangan berdasarkan tabel $2.1(\mathrm{E}=300$ lux $)$

- $\quad$ Fakror depresiasi $(k d)=0.8$

g. Jumlah lampu

Berdasarkan persamaan 9 maka jumlah lampu yang dibutuhkan adalah sebagai berikut:

$$
\begin{aligned}
N & =\frac{E \times A}{\phi \times k p \times k d} \\
N & =\frac{250 \text { lux } \times 30 \mathrm{~m}^{2}}{(2500+850) \times 0.486 \times 0.8}=5.75 \approx 6
\end{aligned}
$$

Dari perhitungan di atas diketahui banyaknya jumlah lampu yang harus dipasang di ruang perawatan VIP masing-masing sebanyak 6 buah memakai jenis lampu yang sama dengan kondisi

\begin{tabular}{|c|c|c|c|c|c|c|c|}
\hline \multirow[b]{2}{*}{ Ruang } & \multirow[b]{2}{*}{$\begin{array}{c}\text { Luas } \\
\left(\mathrm{m}^{2}\right)\end{array}$} & \multirow[b]{2}{*}{$\begin{array}{l}\text { Jenis } \\
\text { lampu }\end{array}$} & \multicolumn{2}{|c|}{ Keadaan Awal } & \multicolumn{3}{|c|}{ Keadaan Standar } \\
\hline & & & $\begin{array}{l}\text { Jumlah } \\
\text { Lampu }\end{array}$ & $\begin{array}{l}\text { Intensitas } \\
\text { Penerang }\end{array}$ & $\begin{array}{c}\text { Jenis } \\
\text { lampu }\end{array}$ & $\begin{array}{l}\text { Jumlah } \\
\text { Lampu }\end{array}$ & \begin{tabular}{|c|} 
Intensitas \\
Penerangan \\
(Lux) \\
\end{tabular} \\
\hline \multirow{2}{*}{$\begin{array}{c}\text { Kamar } \\
\text { rawat } \\
\text { VIP1 }\end{array}$} & \multirow{2}{*}{30} & $\begin{array}{l}\text { TL } 36 \\
\text { Watt }\end{array}$ & 2 & \multirow{2}{*}{84.5} & $\begin{array}{l}\text { TL 36 } \\
\text { Watt }\end{array}$ & 6 & \multirow{2}{*}{300} \\
\hline & & $\begin{array}{l}\text { Essential } \\
14 \text { Watt }\end{array}$ & 4 & & $\begin{array}{l}\text { Essential } \\
14 \text { Watt }\end{array}$ & 6 & \\
\hline
\end{tabular}
awal yaitu TL-D 36W/54-765 ISL/25 dengan daya sebesar 36 Watt dan 6 buah lampu Philips Essential 14 Watt untuk mencapai intensitas penerangan yang standar yaitu 250 lux.

h. Perbandingan Kondisi Awal dan Kondisi Standar Perbandingan ini menunjukan perbedaan kondisi ruang pada keadaan awal dan keadaan standar yang dianjurkan (Tabel 10).

Tabel 10. Perbandingan Kondisi Awal Dan Kondisi Standar Ruang Perawatan VIP 
Tabel 10 di atas menunjukan kamar rawat VIP 1 dengn luas $30 \mathrm{~m}^{2}$ seharusnya dipasang sebanyak 6 buah lampu untuk masing-masing jenis lampu yang sama pada kondisi awal.

\section{Lorong A dan B}

Perhitungan jumlah lampu pada ruang casemix diuraikan secara rinci sebagai berikut:

a. Data ruangan

$\begin{array}{ll}\text { Panjang ruangan }(p) & =15 \mathrm{~m} \\ \text { Lebar ruangan }(l) & =1 \mathrm{~m} \\ \text { Tinggi ruangan }(t) & =3 \mathrm{~m}\end{array}$

Tinggi sumber cahaya di atas bidang kerja $(h)=2.2$ $\mathrm{m}(3.0 \mathrm{~m}-0.8 \mathrm{~m})$

b. Indeks ruangan $(k)$

Dengan menggunakan persamaan 7 maka indeks ruangan ditentukan sebagai berikut:

$$
\begin{aligned}
k & =\frac{p \times l}{h(p+l)} \\
\mathrm{k} & =\frac{15 \times 1}{2.2(15+1)}=0.43
\end{aligned}
$$

\section{c. Faktor refleksi}

Dengan mengacu pada Tabel 3 dan 4, maka faktor refleksi di lorong A dan B adalah:

Faktor refleksi langit-langit $(r p) \quad=0.7$

Faktor refleksi dinding $(r w) \quad=0.5$

Faktor refleksi lantai $(\mathrm{rm}) \quad=0.1$

d. Efisiensi penerangan

Dari perhitungan indeks ruangan dan ketentuan faktor refleksi mengacu pada Tabel 4 tentang efisiensi penerangan maka diperoleh efisiensi penerangan sebagai berikut:

$\begin{array}{ll}k_{1} & =0.5 \\ k_{2} & =0.6 \\ k p_{1} & =0.26 \\ k p_{2} & =0.30\end{array}$

e. Faktor utility $(k p)$

Dengan mengunakan persamaan 8 maka besarnya faktor utility adalah sebagai berikut:

$$
\begin{aligned}
k p & =k p_{1}+\frac{k-k_{1}}{k_{2}-k_{1}}\left(k p_{2}-k p_{1}\right) \\
\mathrm{kp} & =0.26+\frac{0.43-0.5}{0.5-0.6}(0.30-0.26)=0.232
\end{aligned}
$$

f. Penentuan jumlah lampu

- Menggunakan lampu TL-D 36 W/54-762 = 36 Watt

- Fluks lampu = 2500 lumen

- Standar intensitas penerangan berdasarkan tabel 2.1 ( $\mathrm{E}=200$ lux $)$

- Fakror depresiasi $(k d)=0.8$

g. Jumlah lampu

Berdasarkan persamaan 9 maka jumlah lampu yang dibutuhkan adalah sebagai berikut:

$$
N=\frac{E \times A}{\phi \times k p \times k d}
$$

$$
N=\frac{200 \operatorname{lu} \times x 15 \mathrm{~m}^{2}}{2500 \times 0.232 \times 0.8}=6.46 \approx 7
$$

Dari perhitungan di atas diketahui banyaknya jumlah lampu yang harus dipasang di Lorong A dan B masing-masing sebanyak 7 buah memakai jenis lampu yang sama dengan kondisi awal untuk mencapai intensitas penerangan yang standar yaitu 200 lux.

h. Perbandingan Kondisi Awal dan Kondisi Standar

\begin{tabular}{|c|c|c|c|c|c|c|c|}
\hline \multirow[b]{2}{*}{ Ruang } & \multirow[b]{2}{*}{$\begin{array}{c}\text { Luas } \\
\left(\mathrm{m}^{2}\right)\end{array}$} & \multirow[b]{2}{*}{$\begin{array}{l}\text { Jenis } \\
\text { lampu }\end{array}$} & \multicolumn{2}{|c|}{ Keadaan Awal } & \multicolumn{3}{|c|}{ Keadaan Standar } \\
\hline & & & $\begin{array}{l}\text { Jumlah } \\
\text { Lampu }\end{array}$ & $\begin{array}{l}\text { Intensitas } \\
\text { Penerang }\end{array}$ & $\begin{array}{l}\text { Jenis } \\
\text { lampu }\end{array}$ & $\begin{array}{l}\text { Jumlah } \\
\text { Lampu }\end{array}$ & \begin{tabular}{|c|} 
Intensitas \\
Penerangan \\
(Lux) \\
\end{tabular} \\
\hline Lorong A & 15 & $\begin{array}{l}\text { TL } 36 \\
\text { Watt }\end{array}$ & 2 & 18.2 & $\begin{array}{l}\text { TL } 36 \\
\text { Watt }\end{array}$ & 7 & 200 \\
\hline Lorong A & 15 & $\begin{array}{l}\text { TL } 36 \\
\text { Watt }\end{array}$ & 2 & 22.4 & $\begin{array}{l}\text { TL 36 } \\
\text { Watt }\end{array}$ & 7 & 200 \\
\hline
\end{tabular}
Perbandingan ini menunjukan perbedaan kondisi ruang pada keadaan awal dan keadaan standar yang dianjurkan (Tabel 11).

Tabel 11. Perbandingan Kondisi Awal Dan Kondisi Standar Lorong A Dan B

Tabel di atas menunjukan bahwa kecilnya intensitas penerangan pada hasil pengukuran salah satu penyebabnya adalah kurangnya jumlah lampu yang seharusnya dipasang pada ruangan dengan luas $15 \mathrm{~m}^{2}$ dengan sumber pencahayaan lampu TL-D 36W/54-765 ISL/25.

\section{Analisis Perhitungan Penambahan Beban Listrik Pada} Perbaikan Intensitas Penerangan

Dari analisis pada sub bab B telah diketahui jumlah penambahan beban pencahayaan pada masing-masing ruangan. Dari data-data tersebut maka diketahui penambahan beban listrik berdasarkan perbaikan intensitas penerangan pada Tabel 12 berikut:

Tabel 12. Total Daya Penambahan Beban Pencahayaan Pada Perbaikan Intensitas Penerangan

\begin{tabular}{|c|l|l|c|r|r|}
\hline No. & Nama Ruangan & Jenis Beban & $\begin{array}{c}\text { Jumlah } \\
(\text { Unit })\end{array}$ & $\begin{array}{c}\text { Daya / Unit } \\
\text { (Watt) }\end{array}$ & $\begin{array}{c}\text { Total Daya } \\
\text { (Watt) }\end{array}$ \\
\hline 1 & Casemix & Lampu TL & 6 & 36 & 216 \\
\hline 2 & Rekam Medis & Lampu TL & 5 & 36 & 180 \\
\hline \multirow{2}{*}{3} & Kamar rawat & Lampu TL & 4 & 36 & 144 \\
\cline { 2 - 6 } & VIP1 & Lampu Essential & 2 & 14 & 28 \\
\hline 4 & Lorong & Lampu TL & 5 & 36 & 180 \\
\hline \multicolumn{5}{|c|}{ Total } \\
\hline
\end{tabular}

Dari Tabel 12 di atas diketahui bahwa total daya penambahan beban pencahayaan pada perbaikan intensitas penerangan sebesar 748 Watt.

\section{KESIMPULAN DAN SARAN}

A. Kesimpulan

Dari hasil analisis data pada Bab IV maka dapat diambil kesimpulan sebagai berikut:

1. Dari data historis diperoleh nilai IKE (Intensitas Konsumsi Energi) listrik terhadap luasan total untuk gedung RS Medirossa Cikarang sebesar 276.617 
$\mathrm{kWh} /$ tahun $/ \mathrm{m}^{2}$ pada tahun 2016 dan 284.603 $\mathrm{kWh} /$ tahun $/ \mathrm{m}^{2}$ untuk tahun 2017 , nilai ini lebih kecil dari standar IKE (Intensitas Konsumsi Energi) listrik untuk bangunan rumah sakit yaitu sebesar 380 $\mathrm{kWh} /$ tahun $/ \mathrm{m}^{2}$. Nilai ini menunjukan bahwa penggunaan energi listrik di RS Medirossa Cikarang termasuk dalam kategori efisien, namun belum memenuhi standar minimum intensitas konsumsi energi pada ruang yang dilakukan survei pencahayaan (ruang casemix, rekam medis, perawatan VIP, dan lorong).

2. Untuk mencapai intensitas penerangan standar pada ruang yang dilakukan survei, maka perlu penambahan 20 lampu TL 36 Watt dan 2 lampu essential 14 Watt yang mengakibatkan penambahan beban listrik sebesar 748 Watt.

\section{B. Saran}

B.1 Untuk Perusahaan

1. Untuk efisiensi daya yang lebih optimal dapat dilakukan penggantian beban pencahayaan lampu TL dan Essential menjadi lampu hemat energi dengan daya yang lebih kecil namum memiliki fluks cahaya yang lebih besar.

2. Dalam perencanaan perluasan bangunan, perlu dilakukan evaluasi lebih lanjut untuk menghitung penambahan kapasitas trafo dan generator. Mengingat pemakaian suplai daya saat ini sudah mendekati batas maksimum yang ditentukan oleh PLN.

\section{B.2 Untuk Penelitian Selanjutnya}

1. Diperlukan perhitungan mengenai pembiayaan atau investasi dalam perencanaan penambahan beban listrik.

2. Diperlukan analisis mengenai faktor daya untuk mencapai pemakaian daya yang lebih optimal.

\section{DAFTAR PUSTAKA}

[1] Badan Standarisasi Nasional. SNI-03-6196-2011. "Prosedur Audit Energi Pada Bangunan Gedung". 2011.

[2] ASEAN-USAID. 1992. Building Energy Concervation Project. ASEAN-Laurence Barkeley Laboratory.

[3] Mark Karlen. James Benya. 2007. Dasar-Dasar Desain Pencahayaan. Jakarta, Erlangga.

[4] Badan Standarisasi Nasional. SNI 6197:2011. "Konservasi Energi Pada Sistem Pencahayaan". 2011.

[5] Muhaimin. 2001. Teknologi Pencahayaan. PT. Refika Aditama. Bandung.

[6] Hendra Rizki. 2007. Audit Energi Pada Gedung RS Dr. Karyadi Semarang. Universitas Diponegoro.

[7] Badan Standarisasi Nasional. SNI 16-7062-2004. "Pengukuran Intensitas Penerangan di Tempat Kerja". 2004. 